\title{
DUAL IMMERSion Digital INSTRUCtion: A Theoretical Model for EQuitable ANd InClusive Classrooms
}

\author{
INSTRUCCIÓN DIGITAL EN DOBLE INMERSIÓN: UN MODELO TEÓRICO PARA AULAS \\ EQUITATIVAS E INCLUSIVAS
}

ENSEIGNEMENT NUMÉRIQUE À DOUBLE IMMERSION : UN MODÈLE THÉORIQUE POUR DES SALLES DE CLASSE ÉQUITABLES ET INCLUSIVES

\author{
Jordi Solsona-Puig, Ed.D. \\ Dual Immersion Teacher, Glendale \\ Unified School District, California, USA. \\ jsolsona@gusd.net \\ https://orcid. \\ org/0000-0001-5522-3189
}

María Capdevila-Gutiérrez, Ph.D. World Languages Department Chair, Glendale Unified School District, California, USA. mcapdevila@gusd.net https://orcid. org/0000-0003-0131-3247

Fernando Rodríguez-Valls, Ph.D. Professor of Secondary Education, California State University, Fullerton, California, USA.

frodriguez-valls@fullerton.edu https://orcid. org/0000-0001-8491-9580

\begin{abstract}
Dual immersion programs have proven effective in achieving biliteracy for all students. However, maintaining equitable practices at the core of such programs has become more challenging in remote learning due to the pandemic. It is necessary, therefore, to revise some of the benefits and challenges of digital instruction mediated by technology in these settings. Using a middle school Dual Immersion (DI) program in Southern California as a background, and from the perspective of bilingual education teachers and professors, this article presents a theoretical model called Dual Immersion Digital Instruction (DI2) that could serve that purpose. The model includes the five dimensions involved in just, equitable, and inclusive education: Technological, content, social, linguistic, and pedagogical. The article also analyzes the pedagogical opportunities and challenges that teachers in DI programs face in regards to each of these dimensions when all instruction becomes fully online. Finally, the article discusses how the shift to online teaching in DI classrooms could impact bilingual teacher education programs.
\end{abstract}

Keywords: Dual immersion; digital instruction; inclusive classrooms; teacher education; remote learning; Covid-19; K-12; online instruction.

\section{RESUMEN}

Los programas de doble inmersión han demostrado ser efectivos en lograr la alfabetización bilingüe para todos los estudiantes. Sin embargo, mantener la equidad en tales programas se ha vuelto más complicado por el aprendizaje a distancia debido a la pandemia. Es necesario, por tanto, revisar los beneficios y retos de la Instrucción Digital mediada por la tecnología en contextos bilingües. Con un programa de Doble Inmersión (DI) de una escuela media situada al sur de California como base, y desde la perspectiva de maestros de escuela y profesores universitarios, este artículo presenta un modelo teórico llamado Instrucción digital en doble inmersión (DI2) que

Received: 2021-02-09 / Accepted: 2021-05-26 / Published: 2021-09-11

https://doi.org/10.17533/udea.ikala.v26n3a16

Special issue on The Role of Technology in Language Teaching and Learning amid the Crisis Generated by the COVID-19 Pandemic. Editors: Marta González-Lloret, University of Hawai'i at Mānoa, uSA; Laia Canals, Universitat Oberta de Catalunya, Spain; Jorge Pineda, Universidad de Antioquia, Colombia.

( $) 2021$ Universidad de Antioquia. This is an open access article distributed under the terms of the Creative Commons License BY-NC-SA 4.0 International. 
permitiría lograr este objetivo. El modelo aborda las cinco dimensiones necesarias para una instrucción inclusiva, justa y equitativa: tecnológica, social, lingüística, de contenido y pedagógica. El artículo también analiza las oportunidades pedagógicas y los retos que los docentes de programas de DI enfrentan en cuanto a estas dimensiones cuando la enseñanza se vuelve completamente en línea. Finalmente, el artículo presenta una reflexión sobre cómo el cambio a la instrucción en línea en programas de DI podría afectar a los programas de preparación docente.

Palabras clave: doble inmersión; instrucción digital; inclusión en el aula; preparación docente; COVID-19; educación primaria y secundaria; aprendizaje a distancia.

\section{RÉSUMÉ}

Les programmes de double immersion se sont avérés efficaces pour atteindre la bilittératie pour tous les élèves. Cependant, le maintien de pratiques équitables, au cœur de ces programmes, est devenu plus difficile dans l'enseignement à distance en raison des épidémies. L'extension de cette phase d'urgence à distance implique la nécessaire révision des avantages et des défis de l'instruction numérique médiée par la technologie. En utilisant un programme de double immersion (DI) au collège dans le sud de la Californie comme contexte, et du point de vue des enseignants et des professeurs d'éducation bilingue, cet article présente un modèle théorique $\left(\mathrm{DI}^{2}\right)$ qui aborde cinq dimensions impliquées dans une approche juste, équitable et une éducation inclusive: technologique, sociale, linguistique, de contenue et pédagogique. Nous explorons les opportunités pédagogiques DI lorsque toutes les instructions deviennent entièrement en ligne, mettant en évidence les pratiques et les implémentations fiables qui devraient améliorer l'enseignement dans les salles de classe di inclusives une fois la phase à distance a terminée. Nous analysons comment les programmes de préparation des enseignants bilingues devraient revoir leurs cadres, le contenu des cours et les outils d'évaluation.

Mots clés: double immersion ; instruction digitale ; inclusion dans la salle de classe ; formation des enseignants ; Covid-19; enseignement primaire et secondaire; apprentissage à distance. 


\section{Introduction: Dual Immersion Equity Beyond Remote Learning}

The global pandemic that struck the world in the spring of 2020 has changed the landscape of education as we knew it. In a time when a large number of school districts in the United States transitioned to remote learning, its reverberation appears to be broad and complex for all stakeholders. The educational response to the pandemics has been diverse all across the United States, but public safety and health principles have been put at the forefront. According to the California Department of Education ( $\mathrm{CDE}$ ) directives for school reopening, more than $90 \%$ of the students continued in the distance learning modality as of February 2021 (CDE, 2020), although the California Department of Public Health (CDPH) stated that "schools throughout the state are currently in various stages of instruction including distance learning, in-person learning, and hybrid instruction based on local conditions" (CDPH, 2021 , p. 1). From the very beginning, administrators and teachers scrambled to balance the risks of feasible K-12 instructional models amidst the worst pandemic of the century, revisiting the educational principles and practices that defined the very foundations of the school system. Analogously, students and parents struggled with the lack of support systems that a physical school provides beyond the design, implementation, and supervision of learning instruction such as nutrition services, childcare, social, and emotional needs. Further concerns regarding technology access, equitable learning environments, academic progress, or the socio-emotional costs have arisen.

The first response to the wave of school closures was to default to some sort of distance learning. Many states, California being one of them, have kept this option as the most prevalent, adjusting to the needs while navigating the surge of infections. While there is no agreement yet on how to call this type of (often improvised) instruction (Fisher et al., 2020), in this article, we will use the term "remote digital instruction" (Hassel \&
Hassel, 2012; Lester \& King, 2009). We opted for the more inclusive concept of Digital Instruction (as opposed to analog instruction), which has a less negative bias than other similar concepts such as online instruction. We may use "online instruction" when embedded in the literature cited. Both forms of instruction are enabled by technology and might be included within the realm of distance learning, which is a more comprehensive concept that includes all instruction not delivered face to face. Distance learning has a long history that goes back to the first mail courses created in the 19th century and has become progressively mediated by the incorporation of new technologies. Other related concepts exist: web-based learning, e-learning, blended or hybrid learning, virtual learning, cyber-learning, etc. With the outbreak of the pandemic, denominations such as emergency or temporary remote learning, online learning, or distance learning have been used interchangeably.

Moving all learning operations from the traditional brick and mortar schools to the digital realm has produced a whole gamut of outcomes, some closer than others to the ideal virtual class -a group of students in cyberspace, as opposed to a classroom as a physical space-. As an ideal concept, it is understood as the interaction of teachers and students applying knowledge to problems utterly mediated by telecommunications and computers in the virtual space (Tiffin \& Rajasingham, 1995). Although the closest reference for these outcomes was online education, the instruction during the initial remote digital instruction phase was a reaction to a dire necessity more than well-designed, digitally oriented instruction. As remote digital instruction settled and became, for many school districts, the widespread option for the fall of the new school year, a revision of its potentialities and challenges as pertaining to dual immersion becomes essential. Certainly, as a type of distance education, K-12 online instruction has endured a dubious reputation; with a somber history since its inception in 1996 (Ferdig et al., 2009). Online instruction was previously reserved to solve aspects such as the lack of remedial courses, 
alternative student placement, crowded schools, or shortage of qualified teachers (Cavanaugh et al., 2009). Nonetheless, in this new reality, online instruction has emerged as the most feasible form to facilitate instruction. Although in education nothing compares yet to non-remote, face-to-face human interaction between teachers and students (Paechter \& Maier, 2010), technology-mediated instruction was increasingly present in the physical classrooms before the pandemic. According to Blake (2013), this type of instruction promoted a shift in the instructional paradigms, from teacher-centered to student-centered learning. At the same time, concerns about equity and learning outcomes have been raised during the remote learning phase (Chandra et al., 2020).

Since Dual Immersion (DI) programs were conceived with equity as their core (Cervantes-Soon et al., 2017), as dual immersion researchers and practitioners, we wanted to explore if the benefits of bilingual education can somehow be transferred equitably on to online learning and be maintained even after the emergency remote phase ceases to exist. The increasing digitalization of K-12 instruction has undeniable potentialities and benefits to enhance the already well-knit DI communities that can be transferred into postpandemic phases. There is a consensus that, despite its potentialities, online classes cannot supplant face-to-face instruction just yet ( $\mathrm{Su} \&$ Foulger, 2019). But can the challenges of online instruction at least be buffered through best practices in a way that ensures the essential objectives of dual immersion? As practitioners and scholars in the field of bilingual education in Southern California, we are enthusiastic about the opportunities of the digitalization of learning as well as concerned with the practical assertions in biliteracy development and the instruction of world languages.

\section{The Five Dimensions of Just, Equitable, and Inclusive Education}

The next sections present an exploratory analysis from five dimensions - technological, content, social, linguistic, and pedagogical- filtered by the sieve of equity. Then, we introduce a theoretical model called Dual Immersion Digital Instruction $\left(\mathrm{DI}^{2}\right)$, pondering its implications in language arts and content instruction in the target language, as well as teacher preparation for dual immersion programs.

\section{Technological, Content Instruction, and Social Dimensions}

The technology dimension epitomizes a long-standing myth in education that technology alone would enhance learning (Goodchild \& Speed, 2019, as cited in Komoski, 1969) which coexisted with the $19^{\text {th }}$ century luddite fear that machinery would dehumanize and harm our society. We have witnessed this same dialog during the emergency remote phase; educational institutions touted that technology-mediated instruction would save the day during the pandemic while others quickly announced the failure of this type of instruction. The reality lies closer to technology being a tool, a powerful one when combined with well-prepared teachers, quality materials, and engaging learning spaces a necessary $\operatorname{cog}$ in the wheel of quality education in the $21^{\text {st }}$ century. Equity concerns due to the digital divide have been at the forefront during remote learning (Chandra et al., 2020), where instruction is mediated by technology, limiting the scope, access, added services, and the effectiveness that analog schooling provides. Distance learning can also produce social and emotional deprivation and can limit engagement (Dorn et al., 2020; Schwartzman, 2020)

Early reports on remote distance learning have pointed to inequalities in accessing technology and content that widens the digital divide and worsens the achievement gap (Chandra et al., 2020). Minorities and deprived groups have a bigger burden when instruction becomes fully online and may have long lasting effects afterwards (Dorn et al., 2020). These authors argue that low-income, black, and Hispanic students are exposed to higher contingencies, at risk of a higher learning loss. From this perspective, it seems that distance learning acts as an 
amplifier of previous problems. Furthermore, physical access to technology is not the only obstacle for certain students and families. Research has pointed out a second and third level to digital divides in terms of types of use of different higher thinking skills, and quality outcomes of educational technology in students with the same digital skills (Scheerder et al., 2017). Precisely, the uneven outcomes of digital instruction have led California legislators to create new legislation, such as the Education finance education omnibus budget trailer bill (CLI, 2020), to guarantee technology access as well as some sort of daily live instruction during the pandemic's remote phase. These and other considerations convey an extra layer when applied to DI programs, where the delivery of content in the target language alone will not suffice.

In general terms, one can argue that technology enhances all levels of instruction and all types of content when used wisely, a tendency that also benefited DI programs. Due to its singularities (Solsona-Puig, 2019), DI programs may present added challenges in translating equitable and inclusive practices into remote digital learning: access and digital literacy of technological tools; the role of students, parents, and teachers; and digital professional development for docents. Along with unequal access to information and communication technologies (ICT) in underprivileged groups, digital instruction requires a more active and mature learner profile (Blake, 2013), positioning the student at the center of its learning process (Rice, 2012). In the family sphere, stay-at-home and digitally literate parents may better facilitate this transition to digital instruction. Conversely, the assumption that technologically savvy students are better learners has been often challenged (Kolikant, 2010; Neumann, 2016), citing aspects such as information illiteracy, shortened attention span, inferior writing skills, predominance of visual over reading information, and technology being a distraction as major pitfalls. Students are not exempt of these technology shortcomings in the $21^{\text {st }}$ century despite K-12 students being labeled as "digital natives", and most of their parents and teachers "digital immigrants" (Prensky, 2001).
Interestingly, technology may not always be closing the digital divide for all but deepening the chasm in equity, affecting all three educational spheres; family, school (teachers, students) and community (Epstein et al., 2009). In their qualitative study on technology access in California high schools, Warschauer et al. (2004) noted that despite having access to similar computer-student ratios, their respective uses, performance, and technology access differed between high and low incomes students. The affectation on low-income students was expanded in an ulterior study of three one-on-one programs in California, Alabama, and Colorado (Warschauer et al., 2014). Apart from curtailing student engagement, which we will address in the next section, it appears that minority parents seem to be less involved or knowledgeable of the school system than affluent families (Machado-Casas et al., 2014).

In the school sphere, proficient teaching during remote digital instruction implies a tech-savvy instructor that masters student engagement without face-to-face interaction (Archambault \& Kennedy, 2014; Hicks, 2011). Teachers are not alien to technology pitfalls: resistance to technology of docents is well documented in literature (Hicks, 2011; Howard, 2013 Tiffin \& Rajasingham, 1995), especially in veteran teachers who comprise up to $40 \%$ of staff (Orlando, 2014). Invariably, however, there is the need for proactive teaching (Fisher et al., 2020). On top of the aforementioned challenges, there is an increasing tendency to digitalize content from print to the virtual format that may forever change the traditional way of teaching and learning: digital literacies may require new strategies and instructional tools to tackle the content both from teachers and students (Hodges \& Matthews, 2020).

In the content dimension, teaching and learning academic content utilizing a world language (sometimes referred as foreign language) is what defines DI programs (CAL, 2021). Due to its specificities, some types of content instruction delivered online have an easier instruction delivery when compared to other subjects, being 
foreign languages (Oliver, 2012; Blake, 2013) and mathematics (Oliver et al., 2010; Sugilar, 2020) more difficult to be taught digitally, resulting sometimes in lower student achievement.

It appears that the transition to a remote digital instruction in DI could potentially hinder the teacher's immediate influence (Ray, 2009) on language learning naturally occurring in face-to-face instruction, which is enhanced by social interaction (Blake, 2013), as well as the live rich interaction between two groups of emergent bilinguals that defines Dual Immersion (Palmer, 2009). Research on DI has frequently stressed the fact that educators in these programs bear an added weight in the attainment of the objectives these programs pursue. DI teachers must utilize an array of resources and strategies that help facilitate content, language, and literacy acquisition in the target languages given the hue of linguistic repertoires and learning stages of emergent bilinguals. These challenges might grow exponentially when instruction cannot be face-to-face instruction.

However, to compensate for the shortcomings of content delivery in digital instruction, technological potentialities may come in handy. One possibility is delivering individualized content through digital means that allows student-paced learning. Once the content is designed and delivered, the immersion students can access it any time provided they have adequate access to it. Pre-recorded lessons, webinars, or other in-class resources are kept in the learning environment to be retrieved as many times as necessary, as opposed to live instruction, that is gone when finished. Additionally, interactive content, multiple media avenues (audio, video, etc.), and open access to enriched content would enhance the learning possibilities. Another option is to ensure that virtual time and space is set up for immersion students to interact (through break-out rooms, collaborative projects, chat or video rooms). There are plenty of possibilities to virtually connect students, schools, and families to enhance the content through the social aspect of immersion programs.
The social dimension is especially important since the students in a dual immersion program rely on social interaction to improve their language skills. Conversely, parent and community involvement are a key component of the success of these types of programs. Frequently, students remain in these programs for many years, and this helps create strong bonds among students, parents, and teachers. Students value this longterm relationship, which becomes a cultural and linguistic investment regarded as positive (Bearse $\&$ de Jong, 2008). Furthermore, parents create a group of strong advocates for quality instruction (Solsona-Puig, 2019). However, DI stakeholders must be vigilant to counterbalance the often referred as "domination of Anglo-white parents" in these programs (Scanlan \& Palmer, 2009; Burns, 2017). Recreating these social interactions digitally has been proven as challenging as necessary. Feelings of isolation or disengagement should be counterbalanced with virtual socialization among students (like birthdays, scavenger hunts, social breaks, etc.), flexibility, and meaningful work (Pretti et al., 2020). Digital student-teacher interaction other than instruction is also necessary in order to maintain and enhance this social dimension. This can be achieved through virtual parties, chat, check-in time before or after class, or other alternative digital interactions.

In the intersection of the technological, content, and social dimensions mentioned above, it seems probable that teachers have a greater influence in the physical classroom to compensate for the existing English cultural dominance (Scanlan \& Palmer, 2009). This is especially true at the early stages of DI programs, where teachers and peers are the main language and cultural role-model for one another. Language and literacy resources used as visual cues (such as images posters, maps, realia, word walls, etc.) or cultural references used as background language are limited to a small two-dimensional screen. Also, limited access to language variations in the class (generally, students share less oral language in online environments with their peers), difficulties in giving immediate individual oral feedback, and the lack of 
student interaction to enhance peer learning might hinder the language and social exchange.

Additionally, the lack of human face-to-face interaction might hinder the well-knit DI social networks that are an essential variable in the success of these programs (Linholm-Leary, 2005). Another added difficulty arises with the lack of ability to influence the language settings in digital platforms; these rarely allow the use of a language other than English. During regular DI instruction, on the contrary, instruction and communication (verbal, written or visual) happen in the target language only. In faceto-face instruction the teacher can better control, expand, or compensate for target language production. In this sense, during the remote digital instruction the precise gauging of content delivery in the target language by the DI teacher -balancing language, culture and content- might be affected.

\section{Equity Through the Linguistic Dimension}

Digital teaching and learning of world languages is by no means a new educational practice. Globalization, travel, and world trade, combined with the need to learn a second language, oftentimes as working adults, have favored the development of a broad variety of online language programs. There are numerous methods, platforms, programs, and applications that, over the years, have developed and implemented more, and improved, virtual spaces and teaching strategies with increasingly better outcomes in language teaching and acquisition (Blake, 2013). Still, world language is one of the disciplines that presents greater challenges in digital learning (Oliver, 2012). Moreover, it is important to remember that the DI classroom requires a twofold focus: the need for target language development and a strong emphasis on literacy development in that target language (Babino \& Stewart, 2017; Ray, 2009). It must also keep its focus on culture maintenance and cultural competence (Palmer, 2009). In that sense, the challenges of digital teaching and learning of world languages are combined with the challenges that pertain to the language arts virtual classroom.
Student engagement is arguably one of the main factors in language learning gains (Zilvinskis et al., 2017). It is also one of the main challenges of the digital classroom in any subject matter. In the DI classroom, though, it is through student verbal participation, oral and written, that the educator is able to check for understanding, assess learning, and adjust instruction for oral language development. Speaking in the target language serves all those functions, but it is also a goal in itself that happens mostly between teachers and students, and less among peers (Ballinger \& Lyster, 2011). Encouraging verbal interaction among students in the DI classroom and providing spaces for it is as essential as challenging.

Dual immersion programs strive to achieve student literacy as well as proficiency in all skills of language: speaking, listening, reading, and writing. Of the four language skills, speaking in the target language requires the strongest teacher support (Potowski, 2004), consequently, it might be the one suffering the most in digital instruction. Thus, getting emergent bilingual students to use the target language in the classroom with consistency should be at the heart of all efforts in digital instruction. In a context of emergent bilingualism, in which teacher and student verbal input is an integral part of learning, student participation and communication are paramount. Communication with peers and teachers is both an essential source of learning as well as one of the most engaging elements in the DI classroom. Thus, in order to meet the linguistic goals of DI, teachers must focus on what is arguably the most challenging aspect of digital teaching: student participation and engagement in the target language.

Accordingly, educators must capitalize on the situation and exploit digital learning to the best of their ability as a tool for academic growth and equity, both social and educational. The bright side of digital instruction is that it can offer students and teachers an array of possibilities for engagement, linguistic growth, and cultural competence (Blake, 2013; Hafner et al., 2015). The alteration of non-verbal communication (Bailenson, 2021), 
context cues, or body language in the physical classroom can be compensated with enhanced digital DI instruction. Interactive voice and video applications, both synchronous and asynchronous, can help teachers and students have a more comprehensive understanding of the language iterations and engage students in both productive and receptive skills. Thus, the four domains of language (reading, speaking, writing, and listening) can be combined in project-based activities, or problem-based tasks that mimic real life, using the target language both as a tool and as a goal (Hampel, 2006.)

An almost infinite amount of real language samples (audio, video, text) is available, providing also a broader variety of accents, lexis, and regional or national linguistic variations that are paramount to the inclusivity of the various cultural and linguistic backgrounds in the classroom. Moreover, the plethora of digital interactive applications for language production (voice, video, etc.) and instructional online games (iCivics, Minecraft,

774 Kahoot, Jeopardy, interactive maps, etc.) help student engagement and enhance their productive and receptive language skills (Chik, 2014).

Online production, whether verbal or written, minimizes student affective filters and maximizes flexible and relaxed synchronous and asynchronous language production and student interactions (Chametzky, 2013). Digital work offers students the possibility of multiple oral attempts through video and audio, self and peer correction, and edition. It is also a way to increase accountability for daily language production for all students, who will be able to produce language and participate at their own time much more often than in the regular classroom setting (Evans, 2009). Analogously, it also grants teachers a number of possibilities for group, small group or individual modifications as well as faster, more frequent and targeted assessments and student self-assessments.

Finally, another important aspect in which digital instruction can serve as a device for equity is that it enhances all students' exposure to cultural information (Evans, 2009) that expands their immediate world experience and cultural capital. For one, it opens the possibility of virtual world travel that gives them access to experiences veiled for some of the students: visits to museums and sites throughout the world, access to art performances in the target language, or ability to connect with people from other countries with whom they can interact in the target language. Language teachers need to be aware of the equalizing opportunities that digital instruction has to offer given that it can help reduce some effects of the socio-economic divide that is, at times, present in the DI classroom.

\section{Pedagogical Dimension: Preparing Teacher \\ Candidates for Just, Equitable, and Inclusive $\mathbf{D I}^{2}$}

In the previous sections, we examined the opportunities and challenges from the technological, linguistic, social, and content dimensions of development and instruction of DI programs. Here, we analyze how the shift to online teaching in Dual Immersion classrooms could impact Bilingual Teacher Preparation Programs (BTPP). Currently, the focus of BTPPS is to enlighten the next generation of culturally and linguistically responsive educators around four guiding principles: (a) bilingualism and biliteracy, (b) academic achievement, (c) socio-cultural competence, and (d) critical consciousness (Alfaro \& Bartolome, 2017; Cervantes-Soon et al., 2017; Howard et al., 2018).

Adding to these four pillars, teacher candidates learn how to embed technology in their lesson design, implementation, and assessment. The integration of technology is guided by the Common Core State Standards Technology Skills (CDE, 2013). These principles guide the design of courses that include, nurture, and foster the candidate's skills in three major areas: language competency, methodology, and culture. It could be argued that once the bilingual teacher candidates have completed a BTTP, they are ready to: (a) work with and learn from students in face-to-face classrooms (Meidl \& Meidl, 2011), (b) use technology as a tool that enhances their practices (Heitink et al., 2016), and (c) prepare students for a global society where multilingualism and technology stand as two key pillars 
(Kelly-Holmes, 2019). Yet, with the new 100\% digital learning reality, these sets of skills will need to be adapted, modified, and enhanced in order to create a just, equitable and inclusive digital learning environments for all DI students and families.

Moreover, BTPps will have to redesign their structure to ensure candidates are equipped with the tools for $\mathrm{DI}^{2}$. An additional challenge will be to prepare candidates to effectively teach in the target language (i.e., Spanish, Vietnamese, Mandarin, Khmer, Hmong) in online settings. Regardless of the teaching and learning setting (online, hybrid, face to face), the outcomes for DI programs have not changed. Students must acquire high levels of biliteracy across all the subject areas --mathematics, history, science-- and to become critical users of languaging (Carpenter et al., 2015).

Before the pandemic, a large number of ВТрР in California programs offered these courses via face-to-face. Traditional teaching is based in orality (Kern \& Schultz, 2005), and teaching and learning online still relies predominantly on the use of voice, but many other communication avenues have opened (chat, icons, smileys, etc.). In that scenario, shifting teacher preparation from face-to-face to online models brings exciting opportunities to ensure just, equitable and inclusive learning in teaching preparation programs. One of the areas in which online learning could enhance the array of opportunities for candidates is the area of clinical work. Before the pandemic, candidates completed their clinical work conducting in-person visits to Dual Immersion classrooms. With this face-to-face possibility out of the map, clinical work must turn virtual. In this virtual set up, candidates may virtually visit and observe Dual Immersion classrooms from any school district across the state. Having more school districts available is especially important for candidates who speak languages such as Vietnamese, Mandarin, Korean, Khmer, and Hmong, among others. The key factor in the effectiveness of this virtual clinical work is to ensure that candidates have access to the same depth and breadth than the one obtained in face-to-face observations (Caprano et al., 2010; Cliffe, 2017).

Another area where possibilities for teacher candidates could increase is the opportunities for virtually conducted ethnographic research. As part of their culture course, candidates have to collect data from a neighborhood and/or community to further understand how cultures and languages are constructed, used, and validated by their inhabitants. The knowledge gained in this exercise serves as the foundation for the candidate's cultural competence and critical consciousness (Paris \& Alim, 2017). The mandate of virtually based practices may open spaces that otherwise would be resistant to an in-person visit and research. As underlined when talking of virtual fieldwork, the key aspect would be to ensure that research, observation, and learning are run within a humanizing framework in which the researcher and participants are open to share, question, and expand their views

To conclude, BTPps have an exciting opportunity to expand how they have been preparing candidates for the last five decades. The drive to continue preparing culturally and linguistically proficient educators will call for seeing technology not as a mere tool to enhance teaching and learning practices but to amplify and empower the opportunities for all language learners to stretch their linguistic repertoires. On the other hand, the TPACK model (Archambault \& Crippen, 2009) presents itself as a concentric Venn diagram that revolves around the knowledge application from three dimensions: Technology, Pedagogy, and Content. Both models can provide equitable education, but as a means to close the opportunity and achievement gap. It would also require teachers to develop, implement, and assess practices that guarantee all DI students develop high levels of bilingualism and acquire subject area biliteracy.

Up to this point, we have examined the five dimensions of just, equitable, and inclusive education in Dual Immersion settings. We have also presented 
the need for Bilingual Teacher Preparation Programs to review and transform their practices. In the next section, we pose what we visualize as a valid model for digital instruction moving forward in the post-pandemic era.

\section{Dual Immersion Digital Instruction $\left(\mathrm{DI}^{2}\right)$ : A Theorical Model for Equity}

Since its beginnings more than two decades ago, the experience in online instruction mostly at the college level (Fish \& Wickersham, 2009) has not produced yet a widely shared model of online distance learning. The attempts to define the types of digital learning have encountered a wide array of variations and constant innovations (Means et al., 2014). Beyond the four online learning categories/ filters outlined by the authors (context, design features, implementation and outcomes), we argue that technology unequivocally determines this type of instruction (Tiffin \& Rajasingham, 1995). Parallelly, there has been a process of digitalizing (Pettersson, 2020) both content and instruction that has affected the way knowledge is delivered and the way teachers plan its delivery. Two models have been recently applied when analyzing the digitalization of instruction: the SAMR and TPACK models (Puentedura, 2014). The SAMR model defines four evolving stages in the application of technology and how its application enhances instruction: Substitution, Augmentation, Modification and Redefinition. Often conceived as a linear model, can actually be seen as complementing the TPACK model, and help together to better understand the digitalization of instruction.

Nonetheless, when applied to DI, both models lack a crucial perspective that lies at the core of these programs: equity (Genesee \& Lindholm-Leary, 2007). In Figure 1, we outlined our model for an equitable Dual Immersion Digital Instruction (with five dimensions: technological, social, linguistic, content, and pedagogical. Thus, each and every interaction for $\mathrm{DI}^{2}$ should be sieved by the prism of equity, that projects its influence on the five dimensions. Through the social dimension, DI programs should consider the utterances and potentialities of

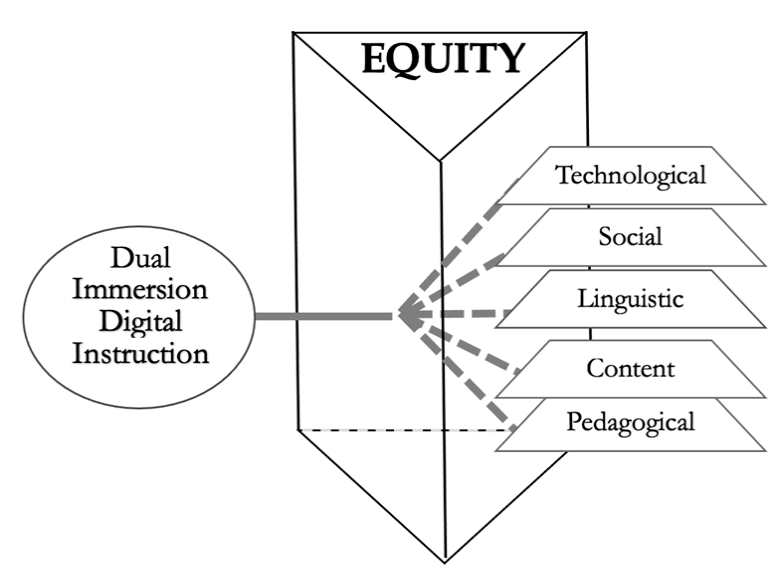

Figure 1 Five Dimensions of the Equitable Dual Immersion Digital Instruction $\left(\mathrm{DI}^{2}\right)$ model.

social interaction mediated by technology. Through the linguistic dimension, DI programs intertwine the cultural and socioeconomic, as well as the language-related aspects of these types of programs when turned into digital instruction. Our theoretical model, $\mathrm{DI}^{2}$ provides a better answer to the unique technological, pedagogical, and content challenges, adding the linguistic and the social dimensions, which are at the core of these programs.

The linguistic dimension is in itself both a goal and a tool paramount to ensure quality instruction and program success. The social dimension is also twofold. It supports the completion of the third pillar of DI, the sociocultural competence (Howard et al. 2018) that is also embedded in the linguistic and content dimensions. At the same time, and equally important, the social environment in DI creates the necessary support structure that helps validate the individual and the community, promotes the sense of belonging, enhances the connection with the educational system and thus, the overall success (Alanis \& Rodriguez, 2008). It is well researched that DI programs are more than mere second language programs, since the language of instruction comes inseparably coupled with the need to maintain and advocate for the often minoritized student culture, and to challenge the raciolinguistic ideologies and coercive relations of power in an English dominant environment (Cummins, 2017; Palmer, 2009; Scanlan \& Palmer, 2009).To this end, we 
present a theoretical model (Figure 1) for just, equitable, and inclusive digital instruction.

Using this new model, practitioners can reflect on educational best practices to digitally counteract the irremediable loss that comes from lack of person-to-person physical interaction. Furthermore, they can impact online instruction may have on the main foci of these programs: linguistic, cultural, and educational equity. We also believe there needs to be a reflection on the idea of building virtual communities in a program that has long relied on an active community building process (Alanis \& Rodríguez, 2008) that is mostly created around inperson interaction.

\section{Recommendations for $\mathbf{D I}^{2}$ Practitioners}

In this section, and using Table 1 as vehicle, we summarize the most important recommendations for an equitable digital instruction in dual immersion programs covered in this article. We combined the four pillars of DI with the five dimensions of the $\left(\mathrm{DI}^{2}\right)$ model in Table 1.

Table 1 Summary of $\mathrm{DI}^{2}$ recommendations

\begin{tabular}{|c|c|c|c|c|c|}
\hline $\begin{array}{l}\text { DI }^{2} \text { dimensions/ } \\
\text { DI pillars }\end{array}$ & Technological & Content & Social & Linguistic & Pedagogical \\
\hline $\begin{array}{l}\text { Bilingualism/ } \\
\text { biliteracy }\end{array}$ & $\begin{array}{l}\text { Teachers, families, } \\
\text { and students need } \\
\text { to be proactive } \\
\text { to enhance } \\
\text { bilingualism and } \\
\text { biliteracy. }\end{array}$ & $\begin{array}{l}\text { Digitalize content. } \\
\text { This may not } \\
\text { decrease its quality } \\
\text { but enhances its } \\
\text { access by interactive } \\
\text { multimedia and } \\
\text { biliteracy tools. }\end{array}$ & $\begin{array}{l}\text { Increase } \\
\text { asynchronous } \\
\text { access and engage } \\
\text { families with } \\
\text { recorded meetings } \\
\text { or videoconferences } \\
\text { and translation } \\
\text { applications. }\end{array}$ & $\begin{array}{l}\text { Think of different } \\
\text { instructional } \\
\text { strategies and tools, } \\
\text { under the light of } \\
\text { digital biliteracies. }\end{array}$ & $\begin{array}{l}\text { Maximize flexible } \\
\text { and relaxed language } \\
\text { production, as verbal } \\
\text { or written digital } \\
\text { production, minimizes } \\
\text { the student affective } \\
\text { filter. }\end{array}$ \\
\hline $\begin{array}{l}\text { High academic } \\
\text { achievement }\end{array}$ & $\begin{array}{l}\text { Consider the three } \\
\text { digital divides: } \\
\text { access, production } \\
\text { quality, and critical } \\
\text { thinking. }\end{array}$ & $\begin{array}{l}\text { Plan for student- } \\
\text { paced content, } \\
\text { multiple access, } \\
\text { and enhanced } \\
\text { organization of } \\
\text { knowledge }\end{array}$ & $\begin{array}{l}\text { Enable peer learning } \\
\text { and socializing } \\
\text { outside class time } \\
\text { through collaborative } \\
\text { virtual projects. }\end{array}$ & $\begin{array}{l}\text { Plan activities } \\
\text { balancing all skills of } \\
\text { the target language: } \\
\text { speaking, listening, } \\
\text { reading, and writing. }\end{array}$ & $\begin{array}{l}\text { Prioritize digital } \\
\text { student engagement } \\
\text { and wellbeing without } \\
\text { overlooking academic } \\
\text { achievement. }\end{array}$ \\
\hline $\begin{array}{l}\text { Cross-cultural } \\
\text { Competence }\end{array}$ & $\begin{array}{l}\text { Compensate for } \\
\text { students (low- } \\
\text { income, Latinx, } \\
\text { Black) that may } \\
\text { suffer bigger } \\
\text { inequalities }\end{array}$ & $\begin{array}{l}\text { Increase } \\
\text { opportunities for } \\
\text { virtually conducted } \\
\text { cultural exchange, } \\
\text { teacher collaboration, } \\
\text { or ethnographic } \\
\text { research. }\end{array}$ & $\begin{array}{l}\text { Gauge cultural and } \\
\text { linguistic bias by } \\
\text { designing social } \\
\text { events and content, } \\
\text { avoiding virtual } \\
\text { fatigue. }\end{array}$ & $\begin{array}{l}\text { Compensate the } \\
\text { loss of non-verbal } \\
\text { communication, } \\
\text { context cues, or } \\
\text { body language in the } \\
\text { physical classroom } \\
\text { or cultural exposure } \\
\text { with enhanced digital } \\
\text { DI instruction }\end{array}$ & $\begin{array}{l}\text { Enhance digital } \\
\text { instruction to improve } \\
\text { equity by increasing } \\
\text { students' exposure to } \\
\text { cultural information } \\
\text { that expands cultural } \\
\text { capital. }\end{array}$ \\
\hline $\begin{array}{l}\text { Critical } \\
\text { Consciousness }\end{array}$ & $\begin{array}{l}\text { Teachers should } \\
\text { counteract digital } \\
\text { platforms' English } \\
\text { dominance and } \\
\text { equalize the } \\
\text { "white-Anglo" } \\
\text { preponderance. }\end{array}$ & $\begin{array}{l}\text { Design lessons with a } \\
\text { culturally respectful, } \\
\text { multimodal approach } \\
\text { to narratives, } \\
\text { individualized and } \\
\text { interactive relation } \\
\text { with literary texts } \\
\text { and content. }\end{array}$ & $\begin{array}{l}\text { Create virtual } \\
\text { spaces for parent } \\
\text { and community } \\
\text { involvement and } \\
\text { participation. }\end{array}$ & $\begin{array}{l}\text { Utilize online real } \\
\text { language samples } \\
\text { (audio, video, text) } \\
\text { to promote a critical } \\
\text { view, more inclusive } \\
\text { of the various } \\
\text { cultural and linguistic } \\
\text { background }\end{array}$ & $\begin{array}{l}\text { Intentionally and } \\
\text { strategically design } \\
\text { instruction that } \\
\text { compensates cultural } \\
\text { bias, limited non- } \\
\text { verbal communication } \\
\text { when teaching online } \\
\text { or hybrid. }\end{array}$ \\
\hline
\end{tabular}




\section{Conclusions}

The $\mathrm{DI}^{2}$ theoretical model embodies a transformative approach for critically enhancing instruction. From a lens of an equitable, just, and inclusive teaching and learning approach, the five dimensions of the $\mathrm{DI}^{2}$ model ensure a comprehensive understanding of the DI classroom. Indeed, ICT's have enhanced most aspects of our lives, including education. Once this emergency remote learning phase fades out, and if we take the potentialities mentioned in previous sections, educators will be left well-equipped with a hue of engaging, inclusive and equitable enhanced digital practices.

However, there isyet much to be done. Opportunities and challenges will be equally present in the months and years to come. The models and strategies designed, implemented, and to some extent assessed during this pandemic stretch have been contextualized within a sort of piloting mode. Teachers and administrators working in Dual Immersion schools adapted their practices to first survive, and later to build the first layers of comprehensive, successful, and inclusive digital instruction.

We are in a much better position now to learn from past experiences. We must continue developing digital teaching and learning practices to enhance the programs and platforms mediated by technology with equity as the main lens. Using and rephrasing the words of Bettina Love (2020), digital teaching beyond survival should be "the practice of working in solidarity with communities of color [in this context multilingual students and families] drawing on the imagination, creativity, refusal, (re)membering, visionary thinking, healing...” (p. 2). Now, it is time to continue exploring, designing, implementing and evaluating new practices.

What is next is a process of growth for the DI community at large. Each participant will attain extra layers of responsibility in the digital instruction era. Among these charges, parents will have to continue to face the need to step in and become active partners in supporting students and teachers in digital learning from the home. Students will have to face the challenges of digital instruction and make every effort to boost their focus and develop their time management skills.

At the same time, they will enjoy the benefits of this self-pacing, student centered, and highly engaging learning system that might be better suited for their needs and age. DI teachers will embody a language role model and become reinforcers and safeguards of the linguistic, cultural, and educational equity promoted in DI programs (Solsona-Puig, Capdevila-Gutiérrez, Rodríguez-Valls, 2018). They will also take the lead of developing all these opportunities for parent involvement and student engagement. Lastly, administrators will be faced with the task to continue to create opportunities for teacher professional development and family digital literacy, as well as to support the potential economic divide that could be affected by the demands of digital instruction.

BTPPs must also review their practices to strengthen their outcomes in order to offer adequate preparation for the next generation of DI teachers. New standards for teacher readiness need to endorse the design and implementation of technology mediated equitable practices. We argue that the $\mathrm{DI}^{2}$ model would greatly help in guiding these efforts.

It is time for all of us to regain credibility as just, equitable and inclusive multilingual educators. As Heifetz and Linsky (2017) point out,

We never know how an intervention is received unless you listen over time. Therefore, just as critical as the quality of your actions will be your ability to hold steady in the aftermath in order to evaluate how to move next. (p. 139)

The aftermath is here, thus, we have to continue questioning ourselves to ensure Dual Immersion programs remain and grow to meet the high expectations students and families have when they enter multilingual classrooms. 


\section{References}

Alanis, I., \& Rodríguez, M. A. (2008). Sustaining a dual language immersion program: Features of success. Journal of Latinos and Education, 7(4), 305-319. https://doi.org/10.1080/15348430802143378

Alfaro, C. \& Bartolomé, L. (2017). Preparing ideologically clear bilingual teachers: Honoring working-class non-standard language use in the bilingual education classroom. Issues on Teacher Education, 26(2), 11-34.

Archambault, L., \& Crippen, K. (2009). Examining TPACK among K-12 online distance educators in the United States. Contemporary issues in technology and teacher education, 9(1), 71-88.

Archambault, L., \& Kennedy, K. (2014) Teacher preparation for K-12 online and blended learning. In R. E. Ferdig \& K. Kennedy (Eds.), Handbook of research on K-12 online learning (pp. 225-244). ETC Press.

Babino, A., \& Stewart, M. A. (2017). "I like English better”: Latino dual language students' investment in Spanish, English, and bilingualism. Journal of Latinos and Education, 16(1), 18-29. https://doi.org/10.1080/ 15348431.2016 .1179186

Bailenson, J. N. (2021). Nonverbal overload: A theoretical argument for the causes of Zoom fatigue. Technology, Mind, and Behavior, 2(1), https://doi.org/10.1037/ tmb0000030

Ballinger, S., \& Lyster, R. (2011). Student and teacher oral language use in a two-way Spanish/English immersion school. Language Teaching Research, 15(3), 289-306.

Bearse, C., \& De Jong, E. J. (2008). Cultural and linguistic investment: Adolescents in a secondary two-way immersion program. Equity \& Excellence in Education, 41(3), 325-340. https:// doi.org/10.1080/10665680802174817

Blake, R. J. (2013). Brave new digital classroom: Technology and foreign language learning. Georgetown University Press.

Burns, M. (2017). “Compromises that we make”: Whiteness in the dual language context. Bilingual Research Journal, 40(4), 339-352. https://doi.org/10.1080/ 15235882.2017 .1388303

Center for Applied Linguistics. Cal (August, 2021). Two Way Immersion Education; the Basics. Retrieved from https://www.cal.org/twi/toolkit/PI/Basics_Eng.pdf

California Department of Education - CDE (2020, June). Stronger together: A guidebook for the safe reopening of California's public schools. Retrieved from: https://www.cde.ca.gov/ls/he/hn/documents/ strongertogether.pdf

California Department of Education - CDE (2013). Common core standards technology skills. Retrieved from: https://www.cde.state.co.us/cdesped/ accommodationsmanual_ccss_k12_techscope

California Department of Health, CDPH. (2021, January). Guidance for COVID-19 school reopening status reporting. Retrieved from: https://www.cdph.ca.gov/ Programs/CID/DCDC/Pages/COVID-19/ School-Reopening-Status-Reporting-Directive.aspx

Caprano, R. M., Capraro M. M. \& Helfeldt, J. (2010). Do differing types of field experiences make a difference in teacher candidates' perceived level of competence? Teacher Education Quarterly, 37(1),131-154.

Carpenter, B. D., Achugar, M., Walter, D., \& Earhart, M. (2015). Developing teachers' critical language awareness: A case study of guided participation. Linguistics \& Education,32A, 82-97. https://doi. org/10.1016/j.linged.2015.03.016

Cavanaugh, C. S., Barbour, M. K., \& Clark, T. (2009). Research and practice in K-12 online learning: A review of open access literature. The International Review of Research in Open and Distributed Learning, 10(1), 1-22. https://doi.org/10.19173/irrodl. v10i1.607

Chandra, S., Chang, A., Day, L., Fazlullah, A., Liu, J., McBride, L., Mudalige, T., Weiss, D., (2020). Closing the $K-12$ digital divide in the age of distance learning. Common Sense Media.

Chametzky, B. (2013). Generalizability and the theory of offsetting the affective filter. Grounded Theory Review, 12(2), 1-14

Cervantes-Soon, C. G., Dorner, L., Palmer, D., Heiman, D., Schwerdtfeger, R., \& Choi, J. (2017). Combating inequalities in two-way language immersion programs: Toward critical consciousness in bilingual education spaces. Review of Research in Education, 41(1), 403427. https://doi.org/10.3102/0091732X17690120

Chik, A. (2014). Digital gaming and language learning: Autonomy and community. Language Learning \& Technology, 18(2), 85-100. https://doi. org/10.1057/9781137290243_6

California Legislature Information - CLI (2020). AB77 Education finance: education omnibus budget trailer. California Senate. Published: 06-29-2020. https://leginfo.legislature.ca.gov/faces/billTextClient.xhtml?bill_id=201920200AB77 
Cliffe, A. D. (2017). A review of the benefits and drawbacks to virtual field guides in today's Geoscience higher education environment. International Journal of Educational Technology in Higher Education, 14, article 28. https://doi.org/10.1186/s41239-017-0066-x

Cummins, J. (2017). Teaching minoritized students: Are additive approaches legitimate? Harvard Educational Review, 87(3), 404-425. https://doi. org/10.17763/1943-5045-87.3.404

Dorn, E., Hancock, B., Sarakatsannis, J., \& Viruleg, E. (2020). COVID-19 and student learning in the United States: The hurt could last a lifetime. McKinsey \& Company.

Epstein, J. L., Sanders, M. G., Sheldon, S. B. Simon, B.; Salinas, K. C., Rodriguez, N., Van Hoorhis, F. L., Martin, C., Thomas, B., Greenfeld, M., Hutchins, D. \& Williams, K. J., (2009). School, family, and community partnerships: Your handbook for action. Corwin Press.

Evans, M. (Ed.). (2009). Foreign language learning with digital technology. A\&C Black.

Ferdig, R. E., Cavanaugh, C., DiPietro, M., Black, E. W. \& Dawson, K. (2009). Virtual schooling standards and best practices for teacher education. Journal of Tech-

Ferdig, R. E., Baumgartner, E., Hartshorne, R., KaplanRakowski, R. \& Mouza, C. (Eds). (2020). Teaching, technology, and teacher education during the COVID-19 pandemic: Stories from the field. Association for the Advancement of Computing in Education (AACE). Retrieved from https://www.learntechlib. org/p/216903/

Fish, W. W., \& Wickersham, L. E. (2009). Best practices for online instructors: Reminders. Quarterly Review of Distance Education, 10(3), 279.

Fisher, D., Frey, N., \& Hattie, J. (2020). The distance learning playbook, grades K-12: Teaching for engagement and impact in any setting. Corwin Press.

Fitzpatrick, A., \& Davies, G. (2003). The impact of Information and Communications Technologies on the teaching of foreign languages and on the role of teachers of foreign languages. EC Directorate General of Education and Culture. European Commission

Freire, P. (2018). Pedagogy of the oppressed (originally published in 1982). Bloomsbury Publishing USA. https://doi.org/10.4324/9780429269400-8

Genesee, F., \& Lindholm-Leary, K. (2007). Dual language education in Canada and the United States. In J. Cummins \& N. Hornberger (Eds.), Encyclopedia oflanguage and education (2 ${ }^{\text {nd }}$ Ed., pp. 253-266). Springer.
Goodchild, T., \& Speed, E. (2019). Technology enhanced learning as transformative innovation: a note on the enduring myth of TEL. Teaching in Higher Education, 24(8), 948-963. https://doi.org/10.1080/135 62517.2018 .1518900

Hafner, C. A., Chik, A. \& Jones, R., eds. (2015) Digital literacies and language learning. Language Learning \& Technology, 19(3), 1-7. http://centaur.reading. ac.uk/51048/

Hassel, B. B. C., \& Hassel, E. A. (2012). Teachers in the age of digital instruction. Education reform for the digital era, 11, 33 .

Hampel, R. (2006). Rethinking task design for the digital age: A framework for language teaching and learning in a synchronous online environment. ReCALL, 18(1), 105-121. https://doi.org/10.1017/ S0958344006000711

Heifetz, R., \& Linsky, M. (2017). Leadership on the line, with a new preface: Staying alive through the dangers of change. Harvard Business Press.

Heitink, M. C., Voogt, J, Verplanken, L., Braak, J., \& Fisser, P. (2016). Teachers' professional reasoning about their pedagogical use of technology. Computers \& Education, 101, 70-83. https://doi.org/10.1016/j. compedu.2016.05.009

Hicks, S. D. (2011). Technology in today's classroom: Are you a tech-savvy teacher? The Clearing House: $A$ Journal of Educational Strategies, Issues and Ideas, 84(5), 188-191. https://doi.org/10.1080/000986 55.2011 .557406

Hodges, T. S., \& Matthews, S. D. (2020). Digital literacies and text structure instruction: Benefits, new language demands, and changes to pedagogy. In Handbook of research on integrating digital technology with literacy pedagogies (pp. 52-71). IGI Global. https://doi. org/10.4018/978-1-7998-0246-4.ch003

Howard, S. K. (2013). Risk-aversion: Understanding teachers' resistance to technology integration. Technology, Pedagogy and Education, 22(3), 357-372. https:// doi.org/10.1080/1475939X.2013.802995

Howard, E. R., Lindholm-Leary, K. J., Rogers, D., Olague, N., Medina, J., Kennedy, B., Sugarman, J., \& Christian, D. (2018). Guiding principles for dual language education ( $3^{\text {rd }} \mathrm{ed}$.). Center for Applied Linguistics.

Kelly-Holmes, H. (2019). Multilingualism and technology: A review of developments in digital communication from monolingualism to idiolingualism. Annual Review of Applied Linguistics, 39, 24-39. https://doi. org/10.1017/S0267190519000102 
Kern, R., \& Schultz, J. M. (2005). Beyond orality: Investigating literacy and the literary in second and foreign language instruction. The Modern Language Journal, 89(3), 381-392.

Kolikant, Y. B. D. (2010). Digital natives, better learners? Students' beliefs about how the Internet influenced their ability to learn. Computers in Human Behavior, 26(6), 1384-1391. https://doi.org/10.1016/j. chb.2010.04.012

Komoski, P. K. (1969). The Continuing Confusion About Technology and Education or The Myth-ing Link in Educational Technology: Epilogue to" ET Around the World". Educational Technology, 9(11), 70-74.

Lester, P. M., \& King, C. M. (2009). Analog vs. digital instruction and learning: Teaching within first and second life environments. Journal of Computer-Mediated Communication, 14(3), 457-483. https:// doi.org/10.1111/j.1083-6101.2009.01449.x

Lindholm-Leary, K. J. (2005). The rich promise of two-way immersion. Educational Leadership, 62(4), 56-59. Retrieved from https://eric.ed.gov/?id=EJ745442

Love, B. (2020). We want to do more than survive: Abolitionist teaching and the pursuit of educational freedom. Beacon Press.

Lütge, C., Merse, T., Owczarek, C., \& Stannard, M. (2019). Crossovers: Digitalization and literature in foreign language education. Studies in Second Language Learning and Teaching, 9(3), 519-540. https://doi. org/10.14746/ssllt.2019.9.3.5

Machado-Casas, M., Sánchez, P., \& Ek, L. D. (2014). The digital literacy practices of Latina/o immigrant parents in an after-school technology partnership. Multicultural Education, 21(3/4), 28.

Means, B., Bakia, M. \& Murphy, R. (2014). Learning online: What research tells us about whether, when and how. Routledge Taylor \& Francis. https://doi. org/10.4324/9780203095959

Meidl, T. \& Meidl, C. (2011). Curriculum integration and adaptation: Individualizing pedagogy for linguistically and culturally diverse students. Current Issues in Education, 14, 1-32

Neumann, C. (2016). Teaching digital natives: Promoting information literacy and addressing instructional challenges. Reading Improvement, 53(3), 101-107.

Oliver, K., Kellogg, S., \& Patel, R. (2010). An investigation into reported differences between online math instruction and other subject areas in a virtual school.
Journal of Computers in Mathematics and Science Teaching, 29(4), 417-453.

Oliver, K. (2012). An investigation into reported differences between online foreign language instruction and other subject areas in a virtual school. Calico Journal, 29(2), 269-296. https://doi.org/10.11139/ cj.29.2.269-296

Orlando, J. (2014). Veteran teachers and technology: change fatigue and knowledge insecurity influence practice. Teachers and Teaching, 20(4), 427-439. https://doi.org/10.1080/13540602.2014.881644

Palmer, D. K. (2009). Middle-class English speakers in a two-way immersion bilingual classroom: "Everybody should be listening to Jonathan right now...”. TESOL Quarterly, 43(2), 177-202.

Paechter, M., \& Maier, B. (2010). Online or face-to-face? Students' experiences and preferences in e-learning. The internet and higher education, 13(4), 292-297. https://doi.org/10.1016/j.iheduc.2010.09.004

Paris, D. \& Alim, S. (Eds.) (2017). Culturally sustaining pedagogies: Teaching and learning for justice in a changing world. Teachers College Press.

Pettersson, F. (2020). Understanding digitalization and educational change in school by means of activity theory and the levels of learning concept. Education and Information Technologies, 26(187-204). https://doi. org/10.1007/s10639-020-10239-8

Potowski, K. (2004). Student Spanish use and investment in a dual immersion classroom: Implications for second language acquisition and heritage language maintenance. The Modern Language Journal, 88(1), 75-101.

Prensky, M. (2001). Digital natives, digital immigrants. On the Horizon, 9(5), 1-6. https://doi. org/10.1108/10748120110424816

Pretti, T. J., Etmanski, B., \& Durston, A. (2020). Remote work-integrated learning experiences: Student perceptions. International Journal of Work-Integrated Learning, 21(4), 401-414.

Puentedura, R. R. (2014). SAMR and TPCK: A hands-on approach to classroom practice. Hipassus. http://www. hippasus.com/rrpweblog/archives/2014/12/11/ SAMRandTPCK_HandsOnApproachClassroomPractice.pdf

Ray, J. M. (2009). A template analysis of teacher agency at an academically successful dual language school. Journal of Advanced Academics, 21(1), 110-141. https://doi.org/10.1177/1932202X0902100106 
Rice, K. (2012). Making the move to K-12 online teaching: Research-based strategies and practices. Pearson.

Scanlan, M., \& Palmer, D. (2009). Race, power, and (in)equity within two-way immersion settings. The Urban Review, 41(5), 391-415. https://doi.org/10.1007/ s11256-008-0111-0

Scheerder, A., van Deursen, A., \& van Dijk, J. (2017). Determinants of Internet skills uses and outcomes. A systematic review of the second-and third-level digital divide. Telematics and Informatics, 34(8), 1607-1624. https://doi.org/10.1016/j.tele.2017.07.007

Schmidt, R. (1993). Awareness and second language acquisition. Annual Review of Applied Linguistics, 13(1), 206-226. https://doi.org/10.1017/ S0267190500002476

Schwartzman, R. (2020). Performing pandemic pedagogy. Communication Education, 69(4), 502-517.

Shanks, D. R., \& St. John, M. F. (1994). Characteristics of dissociable human learning-systems. Behav Brain Sci, 17(3), 367-395. https://doi.org/10.1017/ S0140525X00035032

Solsona-Puig, J. (2019). Transformational leadership in dual language immersion programs; exploring secondary school leaders' perceptions on best practices in Southern California. [Doctoral dissertation], Pepperdine University, Malibu, California. https://digitalcommons.pepperdine.edu/cgi/ viewcontent.cgi ?article $=2029 \&$ context $=$ etd

Solsona-Puig, J., Capdevila-Gutiérrez, M., \& RodríguezValls, F. (2018). La inclusividad lingüística en la educación multilingüe de California: coexisten- cia de las variedades y registros de lengua para enriquecer el aula de inmersión dual. Educación y Educadores, 21(2), 219-236. https://doi. org/10.5294/edu.2018.21.2.3

Su, M. \& Foulger, T. (2019). We aren't there yet: A progression of literature on TPACK measures to assess technology integration. In K. Graziano (Ed.), Proceedings of Society for Information Technology \& Teacher Education International Conference (pp. 2534-2542). Las Vegas, NV, United States: Association for the Advancement of Computing in Education (AACE).

Sugilar, S. (2020, October). Tutors' opinions on students' difficulties of learning mathematics in the distance higher education: A Delphi survey. Journal of Physics, 1663(1), 012009. IOp Publishing.

Tiffin, J., \& Rajasingham, L. (1995). In search of the virtual class: Education in an information society. Psychology Press. https://doi.org/10.4324/9780203291184

Warschauer, M., Knobel, M., \& Stone, L. (2004). Technology and equity in schooling: Deconstructing the digital divide. Educational policy, 18(4), 562-588. https://doi.org/10.1177/0895904804266469

Warschauer, M., Zheng, B., Niiya, M., Cotten, S., \& Farkas, G. (2014). Balancing the one-to-one equation: Equity and access in three laptop programs. Equity \& Excellence in Education, 47(1), 46-62.

Zilvinskis, J., Masseria, A. A., \& Pike, G. R. (2017). Student engagement and student learning: Examining the convergent and discriminant validity of the revised national survey of student engagement. Research in Higher Education, 58(8), 880-903. https://doi. org/10.1007/s11162-017-9450-6

How to cite this article: Solsona-Puig, J., Capdevila-Gutiérrez, M., \& Rodríguez-Valls, F. (2021). Dual immersion digital instruction: A theoretical model for equitable and inclusive classrooms. Íkala, Revista de Lenguaje y Cultura, 26(3), 767-782. https://doi.org/10.17533/udea.ikala.v26n3a16 